\title{
An Innovative Architectural Strategy for the Integration of Energy Issues into the Design Process of a Commercial Center in Switzerland
}

\author{
Emmanuel Rey ${ }^{1,2}$, Willi Frei2 ${ }^{2}$, Sophie Lufkin ${ }^{1 *}$, Dario Aiulfi ${ }^{3}$ \\ ${ }^{1}$ Laboratory of Architecture and Sustainable Technologies (LAST), Institute of Architecture and the City (IA), \\ School of Architecture, Civil and Environmental Engineering (ENAC), Ecole polytechnique fédérale de Lausanne \\ (EPFL), Lausanne, Switzerland \\ ${ }^{2}$ Bauart Architectes et Urbanistes SA, Neuchâtel, Switzerland \\ ${ }^{3}$ Sorane SA, Ecublens, Switzerland \\ Email: sophie.lufkin@epfl.ch
}

Received 18 February 2014; revised 21 March 2014; accepted 29 March 2014

Copyright (C) 2014 by authors and Scientific Research Publishing Inc.

This work is licensed under the Creative Commons Attribution International License (CC BY). http://creativecommons.org/licenses/by/4.0/

cc) (i)

Open Access

\section{Abstract}

In a context of growing efforts to develop sustainability strategies, energy-related issues occupy central stage in the built environment. Thus, the energy performance of housings has improved radically over the past decades. Yet other types of buildings, in particular commercial centers, haven't received the same level of interest. As a result, there is a need for effective and practical measures to decrease their energy consumption, both for heating and electricity. The objective of the paper is to demonstrate that it is possible, through coherent strategies, to integrate energy issues and bioclimatic principles into the design process of commercial centers. It analyzes the exemplary case study of Marin Commercial Center (Switzerland). The interdisciplinary approach, based on integrated design strategies, aimed at increasing the energy efficiency while keeping the cost comparable to the market cost. The main design principles include natural ventilation, nighttime cooling with energy recovery and natural lighting, as well as optimization of mechanical systems. The results of the simulations show that Marin Center attains the best energy performance observed so far among Swiss commercial centers. It also meets the Swiss Minergie standard. The paper thus questions traditional design processes and outlines the need for interdisciplinary evaluation and monitoring approaches tailored for commercial centers. Even though most crucial decisions are taken during the early stages, all phases of the process require systematic optimization strategies, especially operating stages. Recommendations include legal measures, in particular in the fields of ventilation and air-conditioning, education, professional development and technology "Corresponding author.

How to cite this paper: Rey, E., Frei, W., Lufkin, S. and Aiulfi, D. (2014) An Innovative Architectural Strategy for the Integration of Energy Issues into the Design Process of a Commercial Center in Switzerland. Journal of Building Construction and Planning Research, 2, 83-95. http://dx.doi.org/10.4236/jbcpr.2014.22008 
transfer, and financial incentives for the replacement of energy intensive installations.

\title{
Keywords
}

\author{
Energy Efficiency, Commercial Centers, Design Process, Sustainable Architecture, \\ Building Performance
}

\section{Introduction}

In a context of growing efforts to develop sustainability strategies, energy-related issues occupy central stage in the built environment. And with good reason: over $40 \%$ of the worldwide energy consumption can be attributed to the construction sector [1]. In Switzerland, a high urban density country, total energy expenditures associated with buildings account for no less than half of total energy consumption [2], which is a key sustainable development indicator, to the extent that it is currently the number one source of environmental pollution. Indeed, these energy expenditures are the source of significant greenhouse gas emissions, generate a considerable amount of waste, and are associated with the consumption of many material resources for the construction of buildings and infrastructure. Nowadays, many tools exist to estimate and optimize energy performance at building level. However, the vast majority focuses on housing, leaving aside administrative buildings and, even more radically, commercial centers.

As a result, up-to-date information on the energy expenditure of shopping centers is a scarce resource. Various studies have shown that the available data is clearly insufficient in view of the significance of the subject [3]. A recent survey carried out on 32 Swiss commercial centers tried to fill this gap [4]; it highlighted that their average energy expenditure for electricity and heating was much higher than that of office buildings, thus revealing the need to develop and implement effective and practical measures to increase the energy efficiency in this sector. The second chapter of this paper is dedicated to the in-depth presentation of these results, analyzing which factors account for the larger portion on the overall energy expenditure.

In reaction, the objective of the paper is to demonstrate that it is possible, through coherent strategies, to integrate energy issues and bioclimatic principles into the design process of commercial centers. It presents and analyzes the exemplary case study of Marin Center, built in 2011 in the urban region of Neuchâtel [5] [6]. The objective was to attain — at a cost comparable to the market cost - the best energy performance observed so far in Switzerland, with respect both to heating and electricity. The concepts, strategies and methods implemented to reach this goal are described in the third chapter, while the expected energy performance is the focus of chapter four. Based on this example, the conclusion of the paper is the opportunity to broaden the discussion towards the necessity of interdisciplinary evaluation and monitoring approaches tailored for the integration of energy efficiency into the design process of commercial centers. Objectives, measures and recommendations aiming at resolving this issue are presented.

\section{State of the Art}

Within a context of growing effort to develop sustainability strategies in the built environment, there is an increased awareness among architects and planners for the integration of energy efficiency into their projects. This section aims at reviewing the large amount of multi-criteria methodologies designed to evaluate and optimize energy consumption, which resulted from this concern. Basically, they can be classified according to five generic types: 1) Checklists, which provide a list of criteria that help ensuring the consistency and the sustainability of the design (e.g. norms or recommendations of the Swiss Engineers and Architects [7]); 2) Certification methods, or labels, which guarantee the respect of a certain amount of requirements based on the evaluation of the process, regardless of the process, and varying from country to country (e.g. LEED in the USA, Canada and Mexico, BREEAM in the United Kingdom, HQE in France, Minergie in Switzerland); 3) Expert systems, which are software able to answer questions based on known facts and rules (e.g. Lightsolve [8] for daylight aspects); 4) Design-support tools, which provide computer simulations at different scales (e.g. CitySim [9] at city scale); and, finally, 5) Decision-support tools, which provide consistent indicator systems (e.g. Siprius [10] for the regeneration of urban brownfields). 
However, despite the variety of tools and methodologies, it is clear that their impact still remains limited in the practice. Several authors have identified factors such as the difficulty to include these tools effectively in the planning process, the lack of a user-friendly interface, or the difficulties encountered in interpreting and communicating the results, as obstacles [11] [12]. Moreover, the vast majority of these tools focuse on housing, leaving aside administrative buildings and, more specifically, commercial centers. In Switzerland for example, $94 \%$ of the new constructions rewarded by the sustainability label Minergie (which, among other aspects, requires an energy consumption below $40\left[\mathrm{kWh} / \mathrm{m}^{2}\right]$ for heating, warm water, ventilation and electricity) are housings. Administrative and commercial buildings represent respectively $4 \%$ and $1 \%$ of the total share [13]. For the record, the construction and the operation of housing buildings represent roughly $60 \%$ of the primary energy consumed by the total amount of buildings in Switzerland, while administrative, commercial and agricultural buildings represent a share of $27 \%$ [14].

As a result, up-to-date information on the energy expenditure of commercial centers is a scarce resource. Indeed, various studies have shown that the available data is insufficient in view of the significance of the subject, especially when it comes to the specific consumption of certain areas of the building [3]. A survey carried out in 2010 on 32 Swiss commercial centers on behalf of the Federal Office for the Environment (FOEN) tried to fill this gap [4]. Various parameters were calculated; for the purpose of this paper, only results in relation to electricity and heating are presented in the next section.

\subsection{Electricity Energy}

Among the 32 Swiss commercial centers measured by the FOEN survey, the ratio of total electricity consumption (including commercial cooling) to sales area ranges from 311 to $778\left[\mathrm{kWh} / \mathrm{m}^{2}\right.$ per year] (see Figure 1). This average consumption of $556\left[\mathrm{kWh} / \mathrm{m}^{2}\right.$ per year] is five times higher than that of administrative buildings, which have an average electricity consumption of $105\left[\mathrm{kWh} / \mathrm{m}^{2}\right.$ per year].

The main factors influencing these values are the efficiency of the commercial cooling installation and the size of the commercial center (smaller centers, i.e. whose surface vary between 400 and 10,000 $\mathrm{m}^{2}$, have a higher consumption index than bigger ones, probably because their share of commercial cooling is more significant, see Figure 2), but also the air-conditioning equipment, the lighting type and management, the airflows and the ventilation management and, finally, the presence of a restaurant with a kitchen using electricity. The production of commercial cooling, in particular, is a major energy consumer (24\% to $79 \%$ of the total electricity consumption, with an average of 51\%). Efforts to reduce this area of consumption can thus have a significantly positive impact on the global consumption. The average specific consumption per linear meter of refrigeration appliance per year is $5300[\mathrm{kWh} / \mathrm{m}]$; it varies between 3700 and $7700[\mathrm{kWh} / \mathrm{m}]$, depending on the refrigeration production method, the type of refrigeration appliance (size, shape), the temperature level for the heat recovery and the lighting concept for the presentation of goods (power, type of luminary, temporal adjustment). In some cases, in an energy saving perspective, it is better to renounce heat recovery and instead to manage cooling in the most efficient manner.

Ultimately, the study shows that the energy efficiency potential is very dependent on the size of the commercial center. For larger commercial centers (more than $10,000 \mathrm{~m}^{2}$ of sales area), the main challenges are ventilation and air-conditioning; for smaller ones, lighting and commercial cooling are the aspects that require greater attention.

\subsection{Heating Energy}

As shows Figure 3, the annual heat consumption of the 32 measured Swiss commercial centers varies between 21 and $222\left[\mathrm{kWh} / \mathrm{m}^{2}\right.$ per year], with an average of $97\left[\mathrm{kWh} / \mathrm{m}^{2}\right.$ per year].

The most important issues that influence the heating energy index are the typology, age and size of the building, the airflows and the ventilation management, the type of the heat recovery installation (e.g. heat pump system), the level of temperature and the requirements for the premises (set by the user).

\subsection{Comparison with Current Standards}

The measured consumptions were subsequently compared to the new Swiss recommendations formulated in the official standards SIA2024 [15], SIA 380/1 [16] and SIA380/4 [17], which define the state of the art in the field 
Annual electricity energy expenditure index

$\mathrm{kWh} / \mathrm{m}^{2}$ per year

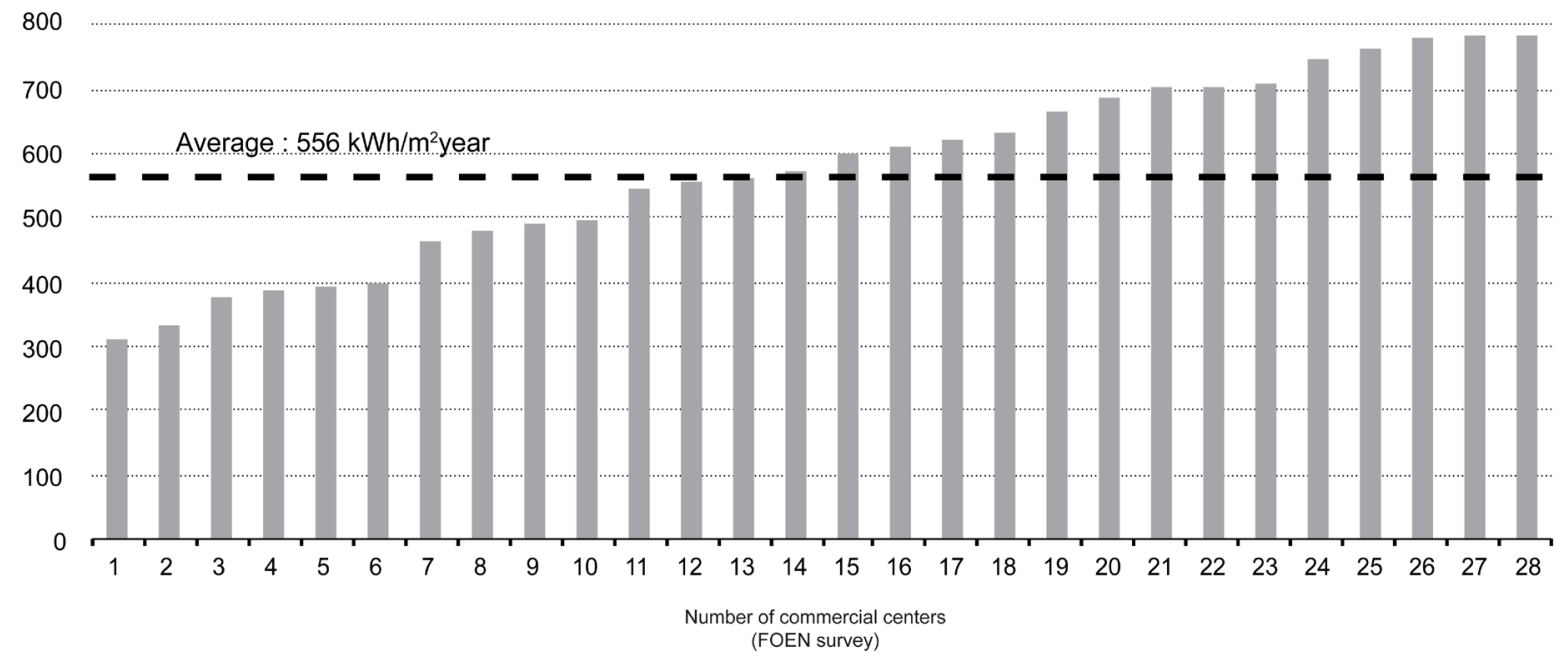

Figure 1. Annual electricity energy expenditure index (including commercial cooling) $\left[\mathrm{kWh} / \mathrm{m}^{2}\right.$ per year].

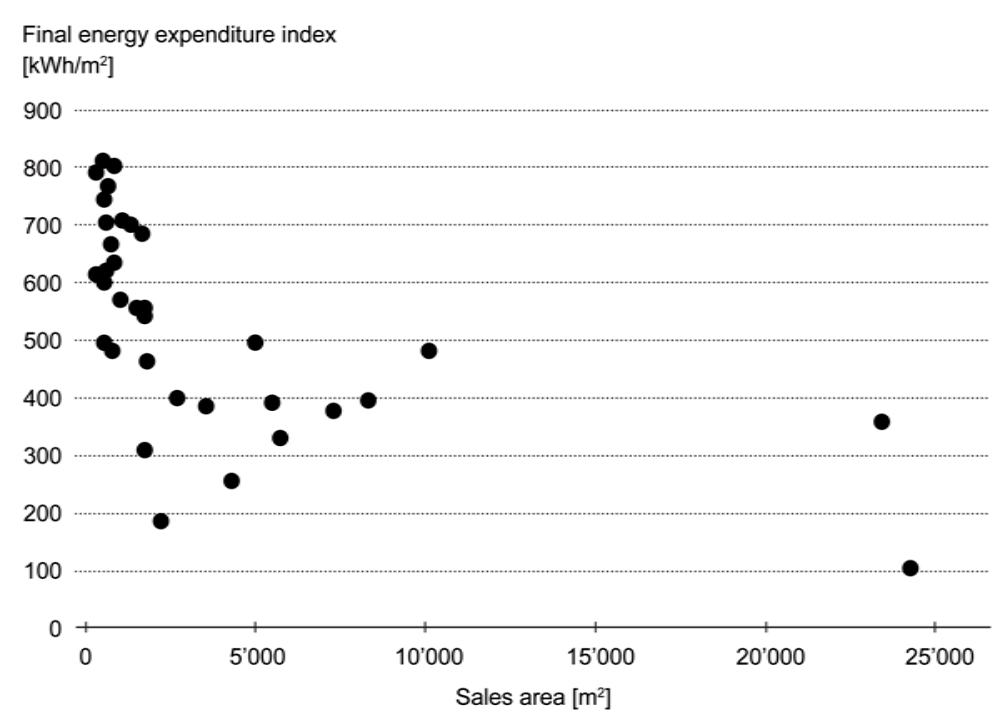

Figure 2. Comparison between the final energy expenditure indexes $\left[\mathrm{kWh} / \mathrm{m}^{2}\right]$ and the sales area $\left[\mathrm{m}^{2}\right]$ of the 32 commercial centers analyzed by the FOEN survey. Each point represents a specific commercial center of the sample.

of construction, and to the results of the RAVEL study [18], published in 1995, which provides a construction and operation guide for managers and owners of commercial centers (see Table 1).

The obtained values, especially for electricity, are clearly higher than those recommended by the actual SIA standards. The target values of the RAVEL study are closer the results of the FOEN survey. However, in view of the improvements achieved in building performance over the past two decades, there is no reason for being satisfied with the standards of 1995.

Vigorous measures are required in order to reach the energy efficiency goals, especially in the fields of ventilation and air-conditioning.

\section{Concept, Strategy and Method: The Example of Marin Center}

In reaction to this shortcoming related to the energy efficiency of commercial buildings, Marin Center, built in 


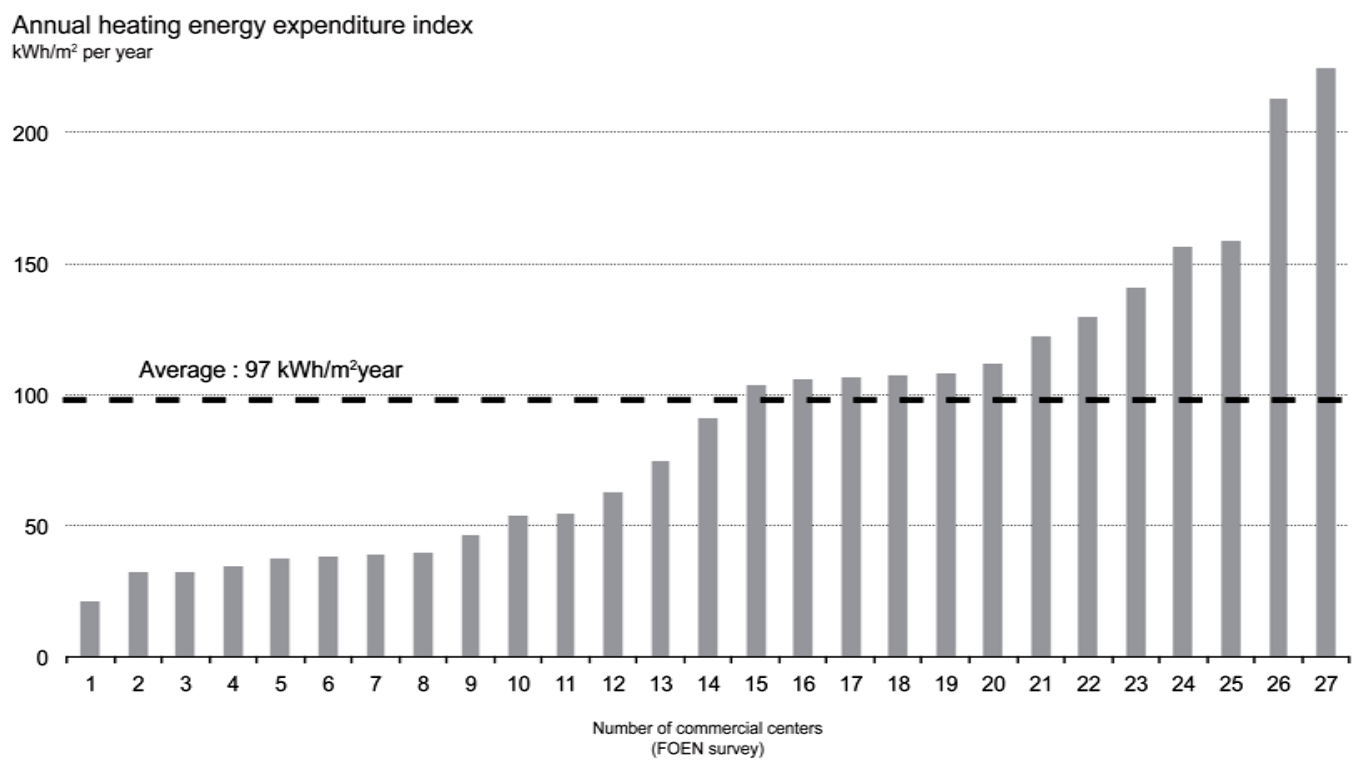

Figure 3. Annual heating energy expenditure index $\left[\mathrm{kWh} / \mathrm{m}^{2}\right.$ per year $]$.

Table 1. Comparison of the average electricity and heat consumption of the 32 commercial centers of the FOEN survey with the SIA 2024, 380/1 and 380/4 standards, and with the RAVEL study.

\begin{tabular}{ccccc} 
& \multicolumn{3}{c}{ Electricity $\left[\mathrm{kWh} / \mathrm{m}^{2} \mathrm{an}\right]$} & Heat $\left[\mathrm{kWh} / \mathrm{m}^{2} \mathrm{an}\right]$ \\
\cline { 2 - 4 } & $<300 \mathrm{~m}^{2}$ & $300-2000 \mathrm{~m}^{2}$ & $>2000 \mathrm{~m}^{2}$ & 80 \\
RAVEL Study (1995) & 500 & 411 & 370 & $71-123^{\text {a) }}$ \\
SIA (2006-2009) & & $70-200$ & 97 \\
FOEN Survey (2010) & 556 & & 97
\end{tabular}

a): Value for a shop with a sales area of $80 \%-50 \%$ of the energy reference area AE.

2011 in the urban region of Neuchâtel (located in an area known as the Swiss Plateau) provides an innovative architectural strategy for the integration of energy issues into the design process of commercial centers. It aimed at standing out from other shopping centers with its coherent design committed to environmentally sustainable development. The objective was to attain — at a cost comparable to the market cost-the best energy performance observed so far in Switzerland, with respect both to heating and electricity. The minimum values for electricity and heat consumption measured within the FOEN survey (respectively $311\left[\mathrm{kWh} / \mathrm{m}^{2}\right]$ and 21 $\left.\left[\mathrm{kWh} / \mathrm{m}^{2}\right]\right)$ were set as target values for the new commercial center.

In addition to economic criteria, a series of ground-breaking environmental priorities were outlined compared with existing centers, most of which are organized around one or several malls with large volumes on one or several levels. The specific characteristics of these structures are notably a comprehensive air-conditioning system including the mall, a practically windowless shell and permanent artificial lighting in interior areas. It is therefore hardly surprising if these shopping centers are the focus of growing criticism for their huge electric energy footprint.

In the case of the Marin Center, the aim was the realization of a shopping mall that fully meets the requirements of sustainable development criteria by using rational energy. The main objective during development of the project was to reach the Minergie standard, especially thanks to natural ventilation and night-time cooling with energy recovery. In particular, the mall was to be a breathing building, naturally ventilated and day-lit (see Figure 4 and Figure 5).

\subsection{Reduction of the Building's Energy Requirements}

The design adopted was based first and foremost on a coordinated strategy for cutting the center's energy needs. Bearing this in mind, the following measures were set in place principally to reduce heat requirements: 


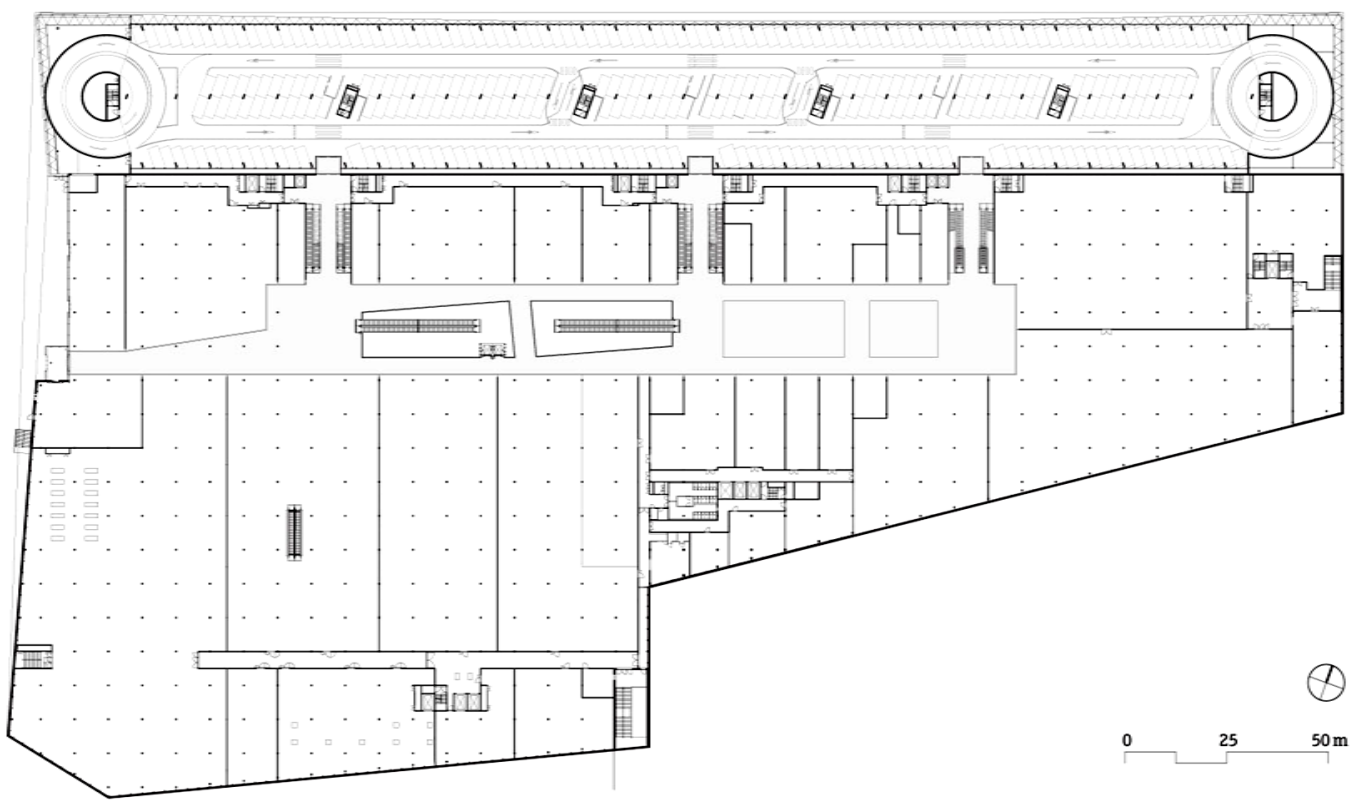

Figure 4. Plan of Marin Center (Bauart).

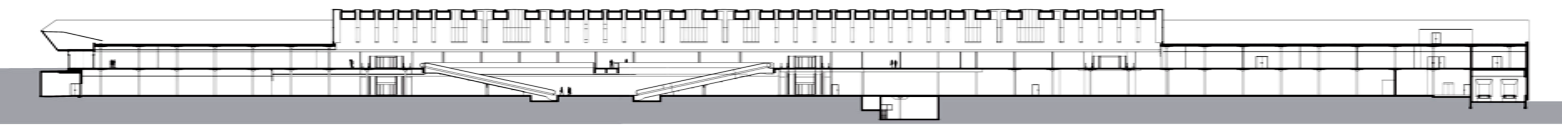

Figure 5. Longitudinal section of Marin Center (Bauart).

- A high-quality thermal shell (reduction of heat loss via the envelope in winter and reduction of undesirable summertime overheating).

- Control of air flows using monobloc units with variation of forced-air flow according to need.

- Heat recovery from the various facilities, especially commercial refrigeration.

- Distribution and emission of low-temperature heating through thermally activated concrete slabs.

- Implementation of high-performance production capacities.

To minimize electricity requirements linked essentially with artificial light and refrigeration, the following measures were factored into the design from the outset:

- Use of natural lighting where possible, notably in the mall and some of the sales areas (specialist retailers).

- Artificial lighting involving efficient low-energy lighting fixtures tailored to actual needs (internal gain control).

- Use of natural ventilation wherever possible in the building and use of passive night cooling to evacuate excess heat accumulated in the building during the day.

- Efficient use of free-cooling with evaporative cooling towers.

- Use of high-efficiency cold production equipment.

- Installation of energy streaming (water and air) with variable flow according to requirements.

- High temperature cooling distribution and emission thanks to thermally activated slabs.

- Careful selection of efficient refrigeration appliance.

\subsection{Thermal Quality of the Building Shell}

Design of the shell not only integrates an aesthetic approach linked with the general concept of the building, but also gives particular attention to its thermal quality. This approach guarantees the reduction of annual running costs without unnecessarily increasing investments. In this type of conversion, extra costs generated by added 
insulation are in fact partially compensated by downsizing technical air-conditioning equipment. This is furthermore facilitated by the fact that the shopping center has extensive blind façade areas which allow easy installation of thick insulation.

Insulation was placed externally to limit thermal bridging, and extra layers on the roof area reduce the need for cooling in summer. Façade U-value is $0.26\left[\mathrm{~W} / \mathrm{m}^{2} \mathrm{~K}\right]$ whereas for the roof it is $0.23\left[\mathrm{~W} / \mathrm{m}^{2} \mathrm{~K}\right]$. All glazing is double with a thin layer of low emissivity coating and inert gas between panes. At $1.1\left[\mathrm{~W} / \mathrm{m}^{2} \mathrm{~K}\right]$, glazing U-value matches current standards for buildings today.

\subsection{Heat Recovery}

Two types of cold production are present on the site, namely climatic cold for active air-cooling of the premises, used in combination with natural ventilation strategies and passive cooling, and commercial cooling for refrigerated display units. Production of climatic cold is used for the iced water network in shops and for ventilation monoblocs. When heating is needed during the winter, regulation is adapted so that climatic cold production is turned off and the system then relies $100 \%$ on free-cooling.

Equipment for commercial cooling ensures efficient refrigeration appliances in sales areas and cold storage. This production mode works all year round, thus providing a valuable source of heat recovery for heating hot water for sanitary use as well as for heating the building (ventilation batteries and thermally activated slabs).

\subsection{Installing Thermally Activated Concrete Slabs}

The activation of the building mass by inserting under floor water coils has been a familiar technique for many years, mainly for heating purposes. It has made a comeback since the development of highly effective façades that enable working with very low heating temperatures $\left(24^{\circ}\right.$ to $30^{\circ} \mathrm{C}$ for water in coils). Low operating temperatures like these, which avoid the uncomfortable feeling linked with ceiling heating, were not possible previously because of inefficient thermal shells, for heating, particular features of this system are the use of natural gas as well as sliding temperature adjustment according to customer needs.

Activated slabs also cool the building mass in summer by using temperatures of roughly $18^{\circ}$ to $20^{\circ} \mathrm{C}$ for the coil water. This cooling system is particularly valuable at night because energy-wise it allows for optimal free-cooling and economy-wise it takes advantage of preferential night rate. The inertia of cement slabs enables use of accumulation or release effect over a cycle of 24 hours. But although the system can easily evacuate 20 to $30 \mathrm{~W} / \mathrm{m}^{2}$, the downside is that it does not adapt well to rapid variations in thermal loads. In the case of a shopping center, a load of about $20 \mathrm{~W} / \mathrm{m}^{2}$ due to lighting is generated all year round (opening and maintenance times). These fixed schedules therefore turn out to be advantageous for efficient integration of the activated slabs into the comprehensive energy concept.

\subsection{Natural Ventilation and Passive Night Cooling}

The potential of natural ventilation is very attractive for the Swiss Plateau. A closer look at the area's weather data shows a significant number of hours (1261 hours) with temperatures ranging from $14^{\circ}$ to $22^{\circ} \mathrm{C}$ between $8 \mathrm{am}$ and $8 \mathrm{pm}$. During this time span, it is advisable from a bioclimatic point of view to use natural ventilation, either to cover $100 \%$ of needs or as a back-up for the mechanical system. Moreover, this daytime potential is enhanced by the addition of night-time hours which allow passive cooling of the building with natural ventilation in certain zones. Although it is difficult to use natural ventilation in some areas such as food shops, particularly where refrigeration appliances are located, this has proved possible in several other sectors.

The central space (see Figure 6) is particularly strategic for natural ventilation. As the volume here is larger than $50,000 \mathrm{~m}^{3}$, it was planned early in the design process not to aim for total temperature control over the whole volume, but rather to take advantage of the Center's impressive height to create stratification and limit heat to the upper part (where there are no customers). Natural ventilation was clearly the solution for climatic management of this volume in response to the following framework conditions:

The large volumes to be dealt with and the solar heat gains to be evacuated would have necessitated installation of particularly energy-greedy air-conditioning systems to guarantee climate control throughout the space.

The central space is a transit zone between the outside and inside of the building with people constantly coming in and out, as well as a passage between shops. This is why climatic conditions swing between these two 


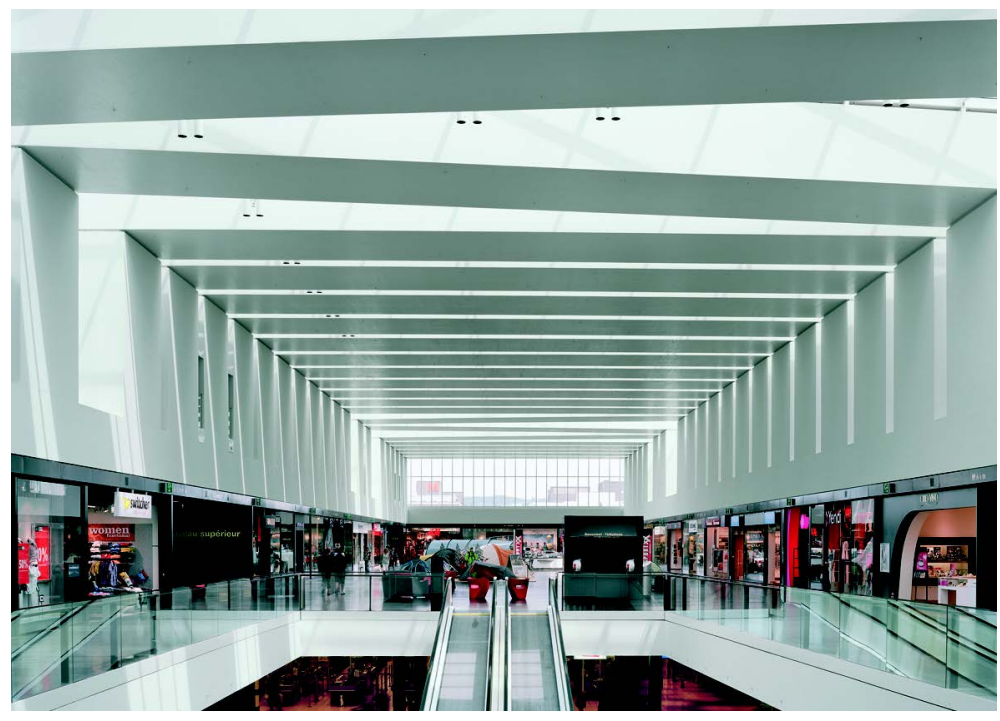

Figure 6. Photography of the central space, looking eastward (Photo: Tonatiuh Ambrosetti).

situations. Ambient requirements agreed on were an indoor temperature of $18^{\circ}$ to $20^{\circ}$ for an outdoor winter temperature of $-6^{\circ}$ and a maximum temperature of $28^{\circ}$ when outdoor summer temperature reaches $32^{\circ}$.

Extensive glazed surfaces ( $276 \mathrm{~m}^{2}$ north side, $276 \mathrm{~m}^{2}$ south side and $695 \mathrm{~m}^{2}$ top-lit) allow large daylight input but also generate significant heat gains, which have to be evacuated in summer and mid-season.

To evacuate the heat load using natural ventilation, a number of out/inlet vents were scheduled in the lower and upper parts of the Center to allow optimal air intake or evacuation from the central area. In the lower part, (ground and first floor) vents were installed to supply air to the mall (total surface area $66 \mathrm{~m}^{2}$ ). Upper floor vents are an integral part of the structure. They are split to cover two equal surfaces at the top and bottom of the structure, covering a total of $128 \mathrm{~m}^{2}$ (32 $\mathrm{m}^{2}$ in the upper northern section, $32 \mathrm{~m}^{2}$ in the upper southern section, $32 \mathrm{~m}^{2}$ in the lower northern section and $32 \mathrm{~m}^{2}$ in the lower southern section.)

Natural ventilation uses a stack effect by opening a certain number of the vents and ventilation ports. The upper vents open progressively, followed by the intermediary ones and finishing with the lower ones. The vents are controlled by the measurement, control and regulation installation, with opening and closing evolving gradually as the need arises (i.e. according to ambient temperature of the central area). During the summer months the vents are also used for night cooling reaching deep inside the building. As soon as inside temperature in the mall rises above outside temperature, the measurement, control and regulation system thus automatically opens the vents. Figure 7 describes air movement: arrows show the direction and colors indicate the speed. When managing the openings with respect to outer temperature and winds, the inner climate is pleasant and there are no airstreams. Figure 8 shows natural ventilation and temperatures in the central space, with an outside temperature of $25^{\circ} \mathrm{C}$. The simulation shows a pleasant temperature at floor level, and an overheat situation in the upper parts, which will activate natural ventilation by simple convection. Figure 9 highlights natural ventilation and vents principles. According to the exterior temperature, various vents can by directly activated to attain the best inner climate, for instance during a hot spell or for night cooling.

\subsection{Optimization of Mechanical Systems}

The climatic cold production uses the free-cooling potential of external air temperature, which allows night-time stoppage of chilling machines during winter and mid-season. In fact the temperature of the chilled water circuit is maintained by exchanging heat with outside air using hybrid cooling towers. These enable use of the ambient wet-bulb temperature instead of that of the "dry air". Dry air is simply humidified by adiabatically spraying it with water before it enters the battery of the cooling tower.

When direct cooling is no longer possible in order to maintain the chilled water circuit at $12^{\circ} \mathrm{C}$, because the wet-bulb air temperature is higher than $10^{\circ} \mathrm{C}$, cooling machines are engaged. The hybrid tower then facilitates 


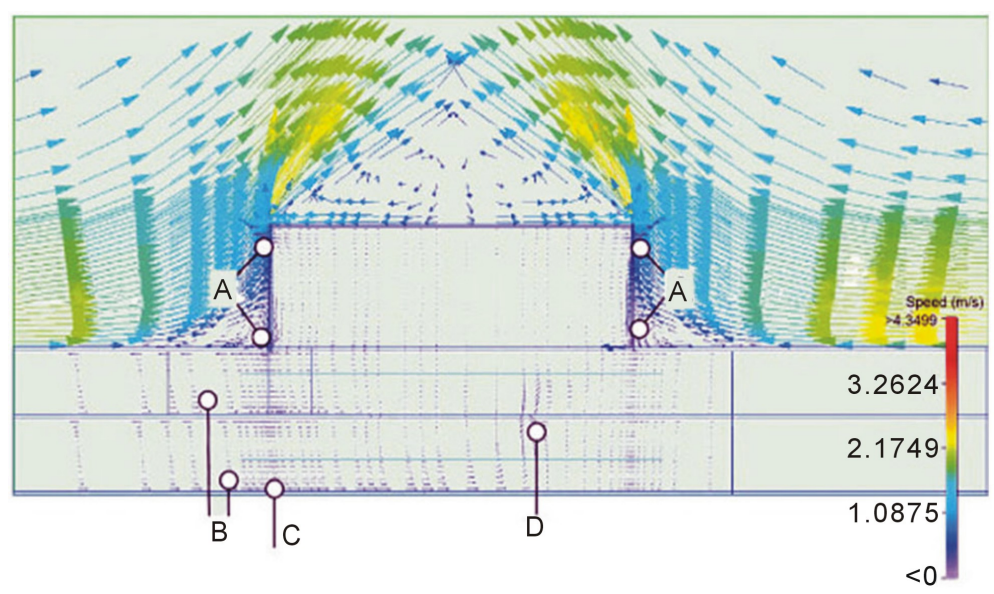

Figure 7. Air movement: arrows show the direction and colors indicate the speed. (A) Open upper vents; (B) Compressed monoblocs in the shops; (C) Closed lower vents; (D) Moderated air speed (Source: Sorane).

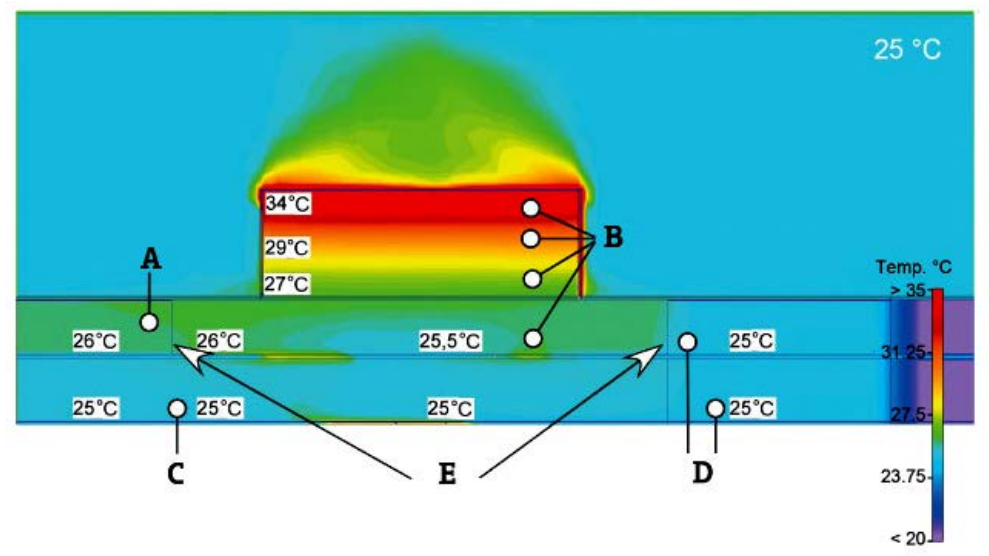

Figure 8. Central space: natural ventilation and temperatures (outside temperature: $25^{\circ} \mathrm{C}$ ). (A) Southern shops (not connected to the central space); (B) Important stratification; (C) Southern shops (connected to the central space); (D) Northern shops (not connected to the central space); (E) Physical separation (showcases) between the shops and the central space (Source: Sorane).

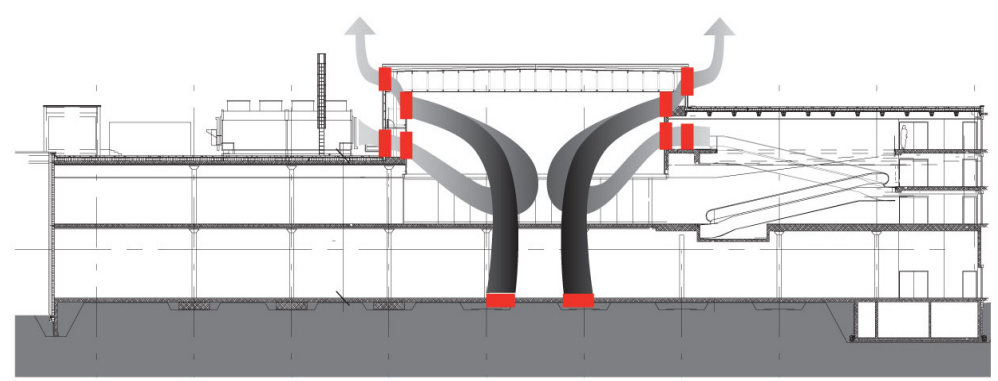

Figure 9. Central space: natural ventilation and vents. (Source: Sorane).

more efficient cooling of condensation from cold production machines and thus improves their efficiency, as well as contributing to significant savings on electricity costs. It should be emphasized here that, as a cooling system, the thermally activated concrete slab is particularly well-suited to night cooling with a hybrid tower, as it can be discharged (cooled) during the night and absorb part of excess heat during the day (day/night phas- 
ing-out effect).

Another goal of the energy concept is shop cooling with a chilled water circuit linked up with the retailers' cooling installations (fan coil units), leaving only the excess internal loads to be evacuated by ventilation. This subtle plus limits the ventilated airflow rate in shopping center areas where internal loads are high.

Specific attention was paid to the efficiency of monobloc ventilation units. In order to be able to recuperate a maximum of heat from the commercial refrigeration facilities and for maximum reduction of losses in the distribution network, heat batteries were optimally scaled to force through air at $25^{\circ} \mathrm{C}$ whereas the heating water temperature is no higher than $35^{\circ}$. The monobloc units are equipped with high-performance recovery systems and air-quality and regulation sensors ensuring finely-tuned functioning adapted to supply and demand (recycling part of the air as climatic conditions require). These recuperators also function in the summer to recover coolness from air extracted, compared to warmer outside air.

Different machines were carefully selected to ensure that the requirements regarding the coefficient of performance proposed by the suppliers are reliable, not only at nominal load but also with partial loads, bearing in mind that most of the time machines function with reduced loads.

Combined with daylight input, the artificial lighting plan was based on energy-saving fixtures providing rationally-adapted ambient light levels. Use of LED technology for certain applications is also an integral part of the approach. All savings on lighting consumption also result in a logical reduction of climatic cold production.

In addition, a solar plant with $400 \mathrm{~m}^{2}$ of photovoltaic captors has been installed on the car park roof by Groupe E, electricity distributor for the cantons of Neuchâtel and Fribourg. Moreover, an extension of this facility where further surface area is available for increasing the share of renewable energy in the electricity network is being considered as part of a long-term goal.

\subsection{Other Environmental Aspects}

In parallel with the reduction of energy consumption, other environmental aspects are also an integral part of the project's approach to sustainable development. For ambient cooling and commercial cold production, different refrigerants are taken into account today in compliance with current standards (R134a, R407c, $\mathrm{NH}_{3}, \mathrm{CO}_{2}$ ). At Marin Center, indoor air is cooled by machines using $\mathrm{R} 134 \mathrm{a}$ and $\mathrm{CO}_{2}$ for commercial cold production. This careful approach has minimized the impact on the greenhouse effect.

To save drinking water, facilities include tap flow restrictors and waterless urinals to reduce overall water consumption.

To manage rain water, the project incorporates drainage and infiltration strategies in landscaped areas (more permeable surfaces on the site) as well as retention areas to avoid pipe clogging and risk of localized flooding (green roof and water storage in case of storms in a ca. $500 \mathrm{~m}^{3}$ capacity tank installed inside one of the spiraling ramps of the car park.) Moreover, the green roof has the added climatic advantage of regulating thermal loads by accumulating heat during the day and releasing it overnight.

As the selection of materials is of the utmost importance in the ecological balance of the building, different measures have been incorporated with regard to favorable life-cycle assessments. One illustrative example is the direct on-site transfer of crushed excavation and demolition material to the new landscaped developments, or use of a wooden structure for the roof of the central area, which enabled a 25-metre beam span, while limiting the grey energy required to erect this emblematic element.

Extensive landscaped development and the large green roof area contribute to creating a much more interesting framework across the whole site in terms of biodiversity compared with the Center as it was.

\section{Performances}

The challenge of Marin Center was to reduce the energy consumption related both to heating and electricity. Indeed, low heat energy expenditures are often correlated to high electricity energy expenditures: energy-greedy commercial cooling installations generate a large amount of heat and therefore ensure comfortable temperature in the premises even on cold days.

As Figure 10 shows, the performance was evaluated separately for heat and electricity consumptions. The cooling and ventilation system final energy expenditures were calculated using respectively the TRNSYS (TRaNsient SYstems Simulation) simulation program and an in-house software developed by Sorane, the engineering consultant responsible for the energy efficiency of Marin Center. For other aspects, data collected in ex- 
isting commercial centers were used, as well as values provided by the Swiss official standard SIA 380/4 [17], which defines benchmark indices for the evaluation of the energy consumption in the early phases of the project.

The process of monitoring is currently under way; the first results tend to confirm those obtained from the simulation (a further publication will provide a detailed account).

These estimated values were then compared to the values measured by the FOEN survey, presented in Sections 2.1 and 2.2 (Figure 11). The expected consumption of Marin Center, both for heat and electricity, is clearly below the average results of the 32 analyzed commercial centers. The expected expenditure for heat (23 $\left[\mathrm{kWh} / \mathrm{m}^{2}\right.$ per year]) is very similar to the minimum value of the FOEN survey sample (21 $\left[\mathrm{kWh} / \mathrm{m}^{2}\right.$ per year] for heat and electricity). The electricity consumption, by contrast, is about 3 times lower than the minimum value of the FOEN survey sample (respectively 114 and $311\left[\mathrm{kWh} / \mathrm{m}^{2}\right.$ per year]). The later result clearly demonstrates the efficiency of the innovative design process of Marin Center.

\section{Conclusions}

The comparison between the energy expenditure indexes measured in the 32 Swiss commercial centers of the FOEN survey and the target values of the current SIA standards calls for a questioning of traditional design

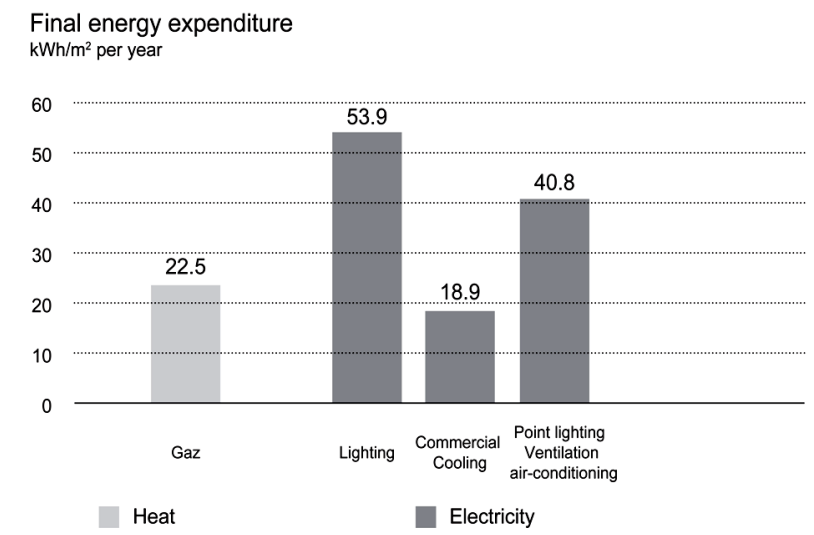

Figure 10. Evaluation of the detailed final energy expenditure of Marin Center (heat and electricity) [kWh/m² per year].

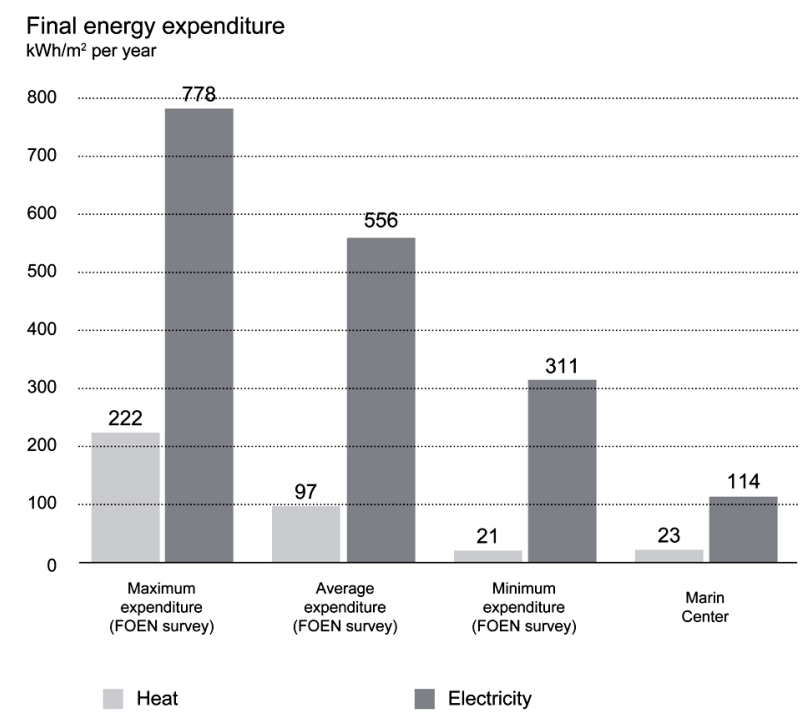

Figure 11. Comparison of the estimated final energy expenditure of Marin Center (heat and electricity) with the values of the FOEN survey [ $\mathrm{kWh} / \mathrm{m}^{2}$ per year]. 
processes. Innovative interdisciplinary approaches for the evaluation and the monitoring of commercial centers have to be created and implemented all along the design process. In the case of Marin Center, for instance, these strategies were applied as early as the stage of competition: the simulation of the project's energy performance was conducted in parallel with the development of architectural design. Even though most of the crucial decisions are taken during the early stages of the design process [19], it is also worth exploring the systematic optimization of the operating stages, especially when the high energy expenditure are related to ventilation and air-conditioning, or when it remains high outside working hours.

Vigorous measures have to be introduced, in particular in the fields of ventilation and air-conditioning. Since their consumptions were very high, commercial centers with relatively small sales areas (below 10,000 $\mathrm{m}^{2}$ ) are especially concerned. This is partly due to their important share of fresh or frozen food products; it can also indicate some weaknesses at the levels of energy-monitoring and building optimization.

Nevertheless, these optimizations require some initial effort. In this perspective, the benchmark models of the Swiss Energy Agency for Economics (AEnEc) [20] and the coupling with pricing systems for electricity based on efficiency (e.g. the EWZ efficiency bonus, developed by the city of Zurich [21]) provide interesting approaches. Strict energy efficiency standards have to be established for office automation, building technology and computer components, in particular for the sleep mode.

In parallel, continued efforts need to be made in the fields of education, professional development and technology transfer towards construction technology and businesses looking for products and services in this area. This involves energy efficient solutions for the operating and cooling of server rooms (e.g. heating and cooling systems operating at a temperature close to the ambient temperature, highly efficient free-cooling solutions or heat recovery from the servers).

In the case of greater commercial centers (over $10,000 \mathrm{~m}^{2}$ of sales area), financial incentives and prescriptions for the replacement of commercial cooling installations and energy intensive refrigeration appliances by highly efficient installations and concepts need to be implemented. Energy concepts for the operating stages should also conciliate the purposes of technology and marketing, and integrate the technical conditions required for the future optimizations of the installations.

In addition to these recommendations, it is important to bear in mind that every situation remains specific. The great variability of the energy expenditure indexes of the 32 studied commercial centers (despite the similarity of the technical installations and equipment) is a clear demonstration of this phenomenon. There is no such thing as a standard procedure or a unique master recipe for moving building practices in a more sustainable direction. This evolution relies more on the realization of "tailor-made solutions" developed iteratively and adapted, both in terms of the project and the building process, to the specificities of the site and the program.

Under many aspects, Marin Center shows that it is possible to incorporate numerous environmental criteria but also various socio cultural elements (balanced integration within the site, easily navigable layout, functionality and flexibility, user comfort, friendly environment and places to meet both inside and outside the center) and economic advantages (investment costs management, limitation of running expenses and external costs due to the building).

Faced with this simultaneous requirement for precision, innovation and flexibility, the approach adopted for this project illustrates in concrete terms how the dynamics of an architectural project can trigger solutions that are simultaneously efficient, creative and unifying for the different actors involved [22]. Through an iterative integration of energy issues into the architectural concept, the approach provided clear and flexible guidelines that served as a basis for optimizing the project, while maintaining overall spatial coherence. More broadly, this conceptual synthesis enabled constant critical assessment of the range of technologies available and meant that sustainability was not considered as a constraint but rather as indispensable "raw material" for the architectural design and decision-making processes [23].

\section{Acknowledgments}

The research on the energy consumption of the 32 Swiss commercial centers was supported by the "Energy Economy - Society (EES)" research program of the Swiss Federal Office of Energy (SFOE) (Project No. 101727). The authors also wish to thank the company of Marin Center SA for being receptive towards the approach presented in this paper. 


\section{References}

[1] Wallbaum, H. (2012) Mainstreaming Energy and Resource Efficiency in the Built Environment—Just a Dream? IED Public Lecture Series, Zurich.

[2] Zimmermann, M., Althaus, H.-J. and Haas, A. (2005) Benchmarks for Sustainable Construction: A Contribution to Develop a Standard. Energy and Buildings, 37, 1147-1157. http://dx.doi.org/10.1016/j.enbuild.2005.06.017

[3] Fisch, N., Plesser, S. and Bremer, C. (2007) EVA—Evaluierung von Energiekonzepten für Bürogebäude. Braunschweig: Institut für Gebäude- und Solartechnik-IGS.

[4] Aiulfi, D., Primas, A., Jakob, M., et al. (2010) Energieverbrauch von Bürogebäuden und Grossverteilen. Erhebung des Strom- und Wärmeverbrauchs, der Verbrauchsanteile, der Entwicklung in den letzten 10 Jahren und Identifizierung des Optimierungspotentiale. Office fédéral de l’Energie (OFEN), Berne.

[5] Architecture Today. The New Marin Centre, Marin-Epagnier, a New Shopping Centre in Switzerland. Architecturetoday.co.uk, 07.02.2012, viewed on 2012.12.07.

[6] Aiulfi, D., Frei, W., Rey, E. and Rota, A. (2011) Architecture durable en pratique. TEC21|TRACES, Dossier 11: 36-49.

[7] http://www.sia.ch/fr/services/sia-norm/

[8] Gagne, J., Andersen, M. and Norford, L. (2011) An Interactive Expert System for Daylighting Design Exploration. Building and Environment, 46, 2351-2364. http://dx.doi.org/10.1016/j.buildenv.2011.05.016

[9] Robinson, D., Haldi, F., Kämpf, J.H., Leroux, P., Perez, D., Rasheed, A. and Wilke, U. (2009) CitySim: Comprehensive Micro-Simulation of Resource Flows for Sustainable Urban Planning. Proceedings of the 11th International Building Performance Simulation Association Conference, Glasgow, 1083-1090.

[10] Rey, E. (2012) Régénération des friches urbaines et développement durable. Vers une évaluation intégrée à la dynamique du projet. Louvain-la-Neuve: Presses universitaires de Louvain (in press).

[11] Weytjens, L., Attia, S., Verbeeck, G. and De Herde, A. (2011) The “Architect-Friendliness” of Six Building Performance Simulation Tools: A Comparative Study. International Journal of Sustainable Building Technology and Urban Development, 2, 237-244. http://dx.doi.org/10.1016/j.buildenv.2011.05.016

[12] Verdonck, E., Weytjens, L., Verbeeck, G. and Froyen, H. (2011) Design Support Tools in Practice. The Architects' Perspective. In: Leclercq, P., Heylighen, A. and Geneviève, M, Eds., CAAD Futures 2011 Proceedings of the 14th International Conference on Computer-Aided Architectural Design, 769-784,

[13] http://www.minergie.ch/liste-des-batiments.html viewed on 2012.12.11

[14] Koschenz, M. and Pfeiffer, A. (2005) Potenzial Wohngebäude. Energie- und Gebäudetechnik für die 2000-Watt-Gesellschaft. Faktor Verlag, Zurich.

[15] Société suisse des ingénieurs et architectes (SIA). SIA Merkblatt 2024, Ausgabe 2006. Standard-Nutzungsbedingungen für Energie- und Gebäudetechnik. SIA, Zurich. 2006.

[16] Société suisse des ingénieurs et des architectes (SIA). SIA 380/1 Thermische Energie im Hochbau. SIA, Zurich. 2009.

[17] Société suisse des ingénieurs et des architectes (SIA). SIA 380/4 Elektrische Energie im Hochbau. SIA, Zurich. 2006.

[18] Guide pour les magasins d'alimentation, RAVEL, Office fédéral des questions conjoncturelles, 1995, 724.323f

[19] Trebilcock, M., Ford, B. and Wilson, R. (2006) Integration of Sustainability in the Design Process of Contemporary Architectural Practice. PLEA 2006-Proceedings of the 23rd Conference on Passive and Low Energy Architecture, Geneva, Switzerland.

[20] http://www.aenec.ch/ viewed on 2012.12.11

[21] Stadt Zürich (2010) Increased Energy Efficiency with a Bonus for Business Clients. Stadtentwicklung, Zurich.

[22] Rey, E. (2011) (Re)construire la ville autrement. Tracés, 17, 7-10

[23] Aiulfi, D. and Rey, E. (2010) Les technologies vertes, matières premières pour la créativité des architectes. Conférence miCro 10, aula des Jeunes-rives, Neuchâtel. 